\title{
Effects of Genotype and Weaning Age Interaction on Growth Traits in Rabbits
}

\author{
Mohamed Ragab ${ }^{1}$, Saad Mohamed Mostfa ${ }^{1}$, Khaled Hassan El-Kholy ${ }^{2 *}$, Lamia M. Radwan ${ }^{3}$, Abeer El-Shafie ${ }^{2}$, \\ and Ibrahim Talat El-Ratel ${ }^{2}$
}

\author{
${ }^{I}$ Department of Poultry Production, Faculty of Agriculture, Kafrelsheikh University, 33516, Kafrelsheikh, Egypt \\ ${ }^{2}$ Department of Poultry Production, Faculty of Agriculture, Damietta University, 34518, Damietta, Egypt \\ ${ }^{3}$ Poultry Production Department, Faculty of Agriculture, Ain Shams University, Cairo, Egypt \\ *Corresponding author's Email: khelkholy@du.edu.eg; (D) ORCiD: 0000-0002-2562-2311
}

\begin{abstract}
Weaning age is an important factor that affects the growth and health of weaned animals. Therefore, the current experiment was conducted to study genotype $(\mathrm{G})$ and weaning age (WA) interaction $(\mathrm{G} \times \mathrm{WA})$ effects on growth traits of the animals belonged to two lines of rabbits (APRI and V line) reared under Egyptian conditions. Multiparous doe rabbits were serviced to obtain 225 litters with 1800 young rabbits at weaning. The weaning ages ranged from 26 to 43 days where the young rabbits were weaned at different ages ( $\geq 28$ days, WA1; $28<$ Treatment $\geq 35$ days, WA2; $35<$ Treatment $\geq 40$ day, WA3 and $40<$ Treatment, WA4). Body weight (BW) from 4 to 16 weeks of age and corresponding average daily gain $\left(\mathrm{ADG}_{\mathrm{t} 1-\mathrm{t} 2}\right)$ were measured. The $\mathrm{BW}$ significantly increased in APRI rabbits, compared to those in $\mathrm{V}$ line at the different ages where at the end of the fattening period, the difference was $105 \mathrm{~g}$ per animal with higher ADG. Regarding the weaning age effects, positive effects were observed where the highest BW was observed at the fattening period. The ADG of rabbits weaned in late weaning was higher than in early weaning with significant differences. The observed results suggest the existence of relevant GXWA interaction for the investigated traits. Therefore, the weaning age of 29-35 days is recommended for young APRI rabbits while it is suggested to wean the V rabbits after 35 days. The study confirmed that early weaning is not preferable for the rabbit under Egyptian conditions and it is better to wean young rabbits at the minimum age of 30 days to achieve the best $\mathrm{BW}$ and growth rate.
\end{abstract}

Keywords: Fattening period, Genotype, Growth traits, Rabbit, Weaning age

\section{INTRODUCTION}

In recent years, interest in rabbit production has increased due to its economic and health importance for humans, as it is considered an ideal solution to the growing protein shortage in developing countries (Dalle Zotte 2002; Petracci et al., 2009; Ebeid et al., 2013). The weaning of rabbit kits is very critical during the life of doe rabbits since it can affect the health status and the growth performance of the weaning kits during the fattening period, particularly during the first post-weaning weeks. Moreover, weaning age has a significant effect on the body condition of the doe rabbits, such as energy deficit and body lipid depots by limiting the duration of lactation and reproduction rhythm (Xiccato et al., 2004; Arias-Alvarez et al., 2009). The health and mortality of weaned rabbits are affected by weaning age (Savietto et al., 2016; Rebollar et al., 2009). With this in mind, it is important to determine the appropriate weaning age when the litter can technically be separated from the does. The results of the weaning age effects on the mortality and the yields of the kits during the fattening are contradictory. Lebas (1993) recommended late weaning to reduce post-weaning mortality. Also, Gidenne and Fortun-Lamothe (2002) found higher mortality between 32 and 45 days in kittens weaned at 23 days than in those weaned at 32 days (17.2 versus $9.2 \%)$.

Other properties that are affected by weaning age include body weight (BW) and gut microbiota (Bennegadi et al., 2003; Gallois et al., 2004). De Blas et al. (1981) found that in 35-day weight of the kits weaned at 25 days was lower than that of animals weaned at 35 days (750 vs. $870 \mathrm{~g}$, respectively) although all finished the bait with the same weight $(2.0 \mathrm{~kg})$ due to the compensatory growth of first ones.

The APRI line was established from Egyptian Baladi Red (BR) and a Spanish line (V) rabbits started in 2002 at the Sakha experimental rabbitry, Animal Production Research Institute, Agricultural Research Center, Ministry of Agriculture, Egypt. The APRI line was founded by crossing Baladi Red bucks with V line does to produce F1 (1/2B1/2V) stock, followed by two generations of inter se matings to achieve performance stability (Youssef et al., 2008 and Abou Khadiga et al., 2010). The V line was established from four different synthetic maternal populations in 1984, crossing crossbred males of two types with crossbred females of two other types. Selection candidates were also genetically 
evaluated for prolificacy at weaning using a repeatability animal model, obtaining Best Linear Unbiased Prediction (BLUP) predictions of their additive genetic value (Estany et al., 1989). A replicate of the V lines was established in 2002 in Sakha and the selection criterion was changed to litter weaning weight as in the APRI line (Youssef et al., 2008). The objective of the current study was to study the effects of genotype and weaning age interaction (G×WA) on growth traits of the animals belonged to two lines of rabbit on kits performance during the fattening period under Egyptian conditions.

\section{MATERIALS AND METHODS}

\section{Ethics approval}

All experimental procedures were approved by the Committee of Ethics and Animal Welfare of Animal Production Research Institute, Sakha, Kafr El-Sheikh Governorate, Egypt.

\section{Animals}

The present study was conducted involving a synthetic Egyptian line (APRI) and a Spanish maternal line (V line). Rabbits were raised at the Experimental Rabbitry of Animal Production Research Institute, Sakha, Kafr El-Sheikh Governorate, Egypt. The analysis included the growth data recorded for APRI and V lines in 2019.

The APRI is a maternal line founded in 2008 at the Animal Production Research Institute, Egypt (Youssef et al., 2008). This line was founded as a synthetic line from the cross of Baladi Red bucks with V line does to get F1. After its foundation, it was selected for litter weaning weight. The V line was established from four specialized maternal lines in 1984 into a composite synthetic line for which the method of evaluating the animals is by Best Linear Unbiased Prediction (BLUP) under a repeatability animal model (Ragab and Baselga, 2011).

The multiparous rabbit does were serviced 12-14 days post-kindling and a pregnancy test was carried out by abdominal palpation on day 14 after mating. Litters born were examined and recorded as a total number of born and the number of those born alive. Litters were reared by their dams until weaning. A total of 1800 rabbits were chosen to be weaned from a litter equalized at birth in 8 kits of 225 litters. At weaning, the young rabbits were individually identified by a number tattooed on the ear. The first age for weaning of kids was $\geq 28$ days (WA1). The second weaning age was 28 $<\mathrm{T} \geq 35$ days included rabbit weaned at 29, 30,31, 32, 33, 34, and 35 days of age (WA2). The third age of weaning was $35<\mathrm{T} \geq 40$ days included rabbit weaned at 36, 37,38, 39, and 40 days of age (WA3). The fourth age of weaning included rabbit weaned at 41, 42, 43 days (40<T days, WA4). At weaning, young rabbits were raised in a semi-closed Rabbitry of commercial type wired cages with standard dimensions $(60 \times 50 \times 35 \mathrm{~cm}$, length $\times$ width $\times$ height $)$ in pyramid-type batteries. The kids were placed in collective cages of about 5 rabbits until 16 weeks of age.

During the post-weaning period, rabbits were fed ad libitum, with a standard commercial pellet diet and fresh water. The diet was composed of $32 \%$ barley, $21 \%$ wheat bran, $10 \%$ soybean meal, $22 \%$ hay, $6 \%$ berseem straw, $3 \%$ molasses, $1 \%$ limestone, $0.34 \%$ table salt, 0.3 minerals and vitamins, 0.06 methionine, and $1.3 \%$ anti-coccidian. This diet included $16.3 \%$ crude protein, $13.2 \%$ crude fiber, $2.5 \%$ either extract, $0.6 \%$ minerals mixture. No serious health problems were observed throughout the experiment.

\section{Traits}

Individual rabbit weights were recorded weekly. Body weight $\left(\mathrm{BW}_{\mathrm{t}}, \mathrm{g}\right)$ was measured at $4\left(\mathrm{BW}_{4}\right), 6\left(\mathrm{BW}_{6}\right), 8$ $\left(\mathrm{BW}_{8}\right), 10\left(\mathrm{BW}_{10}\right), 12\left(\mathrm{BW}_{12}\right), 14\left(\mathrm{BW}_{14}\right)$, and $16\left(\mathrm{BW}_{16}\right)$ weeks of age, which corresponds to age at weeks $4,6,8$, and 10 (the week of slaughter) and the periods from 12 to 16 weeks of age, respectively. Individual average daily gain $\left(\mathrm{ADG}_{\mathrm{t} 1-\mathrm{t} 2}, \mathrm{~g} / \mathrm{d}\right)$ during the study period (4-6 weeks $\left(\mathrm{ADG}_{4-6}\right), 6-8$ weeks $\left(\mathrm{ADG}_{6-8}\right), 8-10$ weeks $\left(\mathrm{ADG}_{8-10}\right), 10-12$ weeks $\left(\mathrm{ADG}_{10-12}\right), 12-14$ weeks $\left(\mathrm{ADG}_{12-14}\right), 14-16$ weeks $\left(\mathrm{ADG}_{14-16}\right)$, overall fattening period $\left(\mathrm{ADG}_{4-10}\right), 6-10$ week $\left(\mathrm{ADG}_{6-10}\right.$, after the critical period of age), 10-16 weeks $\left(\mathrm{ADG}_{10-16}\right)$ and 4 to 16 weeks $\left(\mathrm{ADG}_{4-16}\right)$ of age) were calculated.

\section{Statistical analysis}

The obtained data for the two lines were used in the analysis where univariate animal models were fitted to estimate the genetic parameters for all traits. A total of 2231 individuals were obtained from 371 parities for the two lines were analyzed using the following model:

$\mathrm{y}_{\mathrm{ijklmn}}=\mathrm{YS}_{\mathrm{i}}+\mathrm{PO}_{\mathrm{j}}+\beta(\mathrm{NBA})_{\mathrm{k}}+\mathrm{L}_{\mathrm{l}}+\mathrm{LP}_{\mathrm{m}}+\mathrm{L}_{\mathrm{l}} \times \mathrm{LP}_{\mathrm{m}}+\mathrm{e}_{\mathrm{ijklmn}}$

where,

$\mathrm{y}_{\mathrm{ijklmn}}$ is a record of growth traits, $\mathrm{YS}_{\mathrm{i}}$ denotes a fixed effect, year-season of the parity (one year season every three months: 3 levels), $\mathrm{PO}_{\mathrm{j}}$ signifies a fixed effect, parity order of the doe (3 levels), NBA is a covariate including the number of born alive in the litter in which the animal was born, being $\beta$ the regression coefficient, $\mathrm{L}_{1}$ refers to a fixed effect, line effect (2 levels), $\mathrm{LP}_{\mathrm{m}}$ stands for a fixed effect, lactation-length (4 levels), $\mathrm{L}_{\mathrm{l}} \times \mathrm{LP}_{\mathrm{m}}$ is the effect of line-weaning age interaction, and $\mathrm{e}_{\mathrm{ijklmn}}$ is a random effect, residual of the model. 
To test the significance of the used effects in the model, factorial ANOVA was applied using the GLM procedure of SAS 9.2 (SAS, 2012). The different levels of each effect included in the models were compared using Duncan's multiple range test. A probability of $\mathrm{p} \leq 0.05$ was required for statements of significance.

\section{RESULTS AND DISCUSSION}

Table 1 shows descriptive statistics of the analyzed BW traits, including their number, mean, standard deviation, and minimum and maximum values which take into account the entire data. The actual means of post-weaning BW are within the ranges of the study conducted on the same lines under Egyptian (Youssef et al., 2008; Galal Galal et al., 2013).

Means of BW traits at different weeks of ages for APRI and V lines in the current experiment are presented in Table 2. Differences in weaning weight are economically important where the observed results showed that APRI line was superior over $\mathrm{V}$ line in all BW traits during the whole period of the experiment with significant differences. The difference in BW at 4 weeks of age was around $80 \mathrm{~g}$ in favor of line APRI with a significant difference because fattened rabbits of the APRI line came from litters with the lowest number of kits born alive and the lowest number of rabbits at weaning. Orengo et al. (2004) reported that higher BWs at weaning were obtained when litter size at birth was lower. Moreover, previous studies confirmed that that BW at weaning is associated with milk production (Lukefahr et al., 1983; McNitt and Lukefahr, 1990)

Regarding BW after weaning, the BW differences were in favor of the line APRI and the difference increased with $\mathrm{V}$ line after the 6 weeks of age. At the end of the fattening period $\left(\mathrm{BW}_{10}\right)$, the $\mathrm{BW}$ was higher in the APRI line group, compared to the V line (1706.94 vs. 1601.41). Moreover, the differences at the end of the study period reached to be more than $100 \mathrm{~g}$ per animal favoring the APRI line. This could be partially attributed to the fact that the APRI rabbit could be still affected by its foundation where theoretically containing 50\% of its constituents from Egyptian strain (Red Baldi) genes leading to a higher adaptability level to the Egyptian climatic conditions. APRI rabbits have also benefited from the selection program, which has resulted in genetic improvements in litter weight traits. (Abou Khadiga et al., 2010).

Table 1. Basic statistics for body weight traits at different ages, mean, standard deviation, and extreme values

\begin{tabular}{lccccc}
\hline Traits $(\mathbf{g})$ & $\mathbf{N}$ & Mean & SD & Minimum & Maximum \\
\hline BW $_{\mathbf{4}}$ & 1799 & $472.05 \pm 2.65$ & 112.78 & 226 & 991.5 \\
BW $_{\mathbf{6}}$ & 1799 & $793.40 \pm 3.18$ & 135.07 & 365 & 1531.10 \\
BW $_{\mathbf{8}}$ & 1799 & $1194.87 \pm 3.55$ & 150.84 & 605 & 1950.45 \\
BW $_{\mathbf{1 0}}$ & 1799 & $1655.09 \pm 3.42$ & 145.20 & 1205 & 2450.00 \\
BW $_{\mathbf{1 2}}$ & 1799 & $2057.86 \pm 3.78$ & 160.35 & 1480.9 & 2871.85 \\
BW $_{\mathbf{1 4}}$ & 1720 & $2399.94 \pm 4.09$ & 170.00 & 1770.9 & 3238.60 \\
BW $_{\mathbf{1 6}}$ & 1693 & $2712.53 \pm 4.26$ & 175.49 & 2055 & 3563.90 \\
\hline
\end{tabular}

BW: Body weight at 4, 6, 8, 10, 12, 14, 16 weeks of age. N: Number of observation, SD: Standard deviation.

Table 2. Effect of rabbit lines (APRI and V lines) on body weight at different weeks of age

\begin{tabular}{|c|c|c|c|c|c|c|c|}
\hline Lines & $\mathrm{BW}_{4}$ & $\mathrm{BW}_{6}$ & $\mathrm{BW}_{8}$ & BW $_{10}$ & $\mathbf{B W}_{12}$ & BW $_{14}$ & $\mathrm{BW}_{16}$ \\
\hline APRI & $511.17 \pm 4.07^{\mathrm{a}}$ & $838.01 \pm 4.80^{\mathrm{a}}$ & $1241.04 \pm 5.06^{\mathrm{a}}$ & $1706.94 \pm 4.78^{\mathrm{a}}$ & $2138.62 \pm 5.12^{\mathrm{a}}$ & $2497.33 \pm 5.19^{\mathrm{a}}$ & $2818.19 \pm 5.12^{\mathrm{a}}$ \\
\hline $\mathbf{v}$ & $431.55 \pm 2.79^{b}$ & $747.23 \pm 3.53^{\mathrm{b}}$ & $1147.07 \pm 4.45^{\mathrm{b}}$ & $1601.41 \pm 4.20^{\mathrm{b}}$ & $1974.26 \pm 3.94^{\mathrm{b}}$ & $2300.49 \pm 4.19^{\mathrm{b}}$ & $2604.21 \pm 4.39^{\mathrm{b}}$ \\
\hline
\end{tabular}

$\mathrm{BW}_{4-16}$ : Body weight at 4,6,8,10,12,14,16 weeks of age. ${ }^{\text {a-d }}$ : Means within columns with no common superscript differ significantly (p<0.05). Values are least-squares means.

Table 3. Effect of weaning age on body weight of rabbits at different weeks of age

\begin{tabular}{lccccccc}
\hline WA $(\mathbf{g})$ & $\mathbf{B W}_{\mathbf{4}}$ & $\mathbf{B W}_{\mathbf{6}}$ & $\mathbf{B W}$ & $\mathbf{B W}_{\mathbf{1 0}}$ & $\mathbf{B W}_{\mathbf{1 2}}$ & $\mathbf{B W}_{\mathbf{1 4}}$ & $\mathbf{B W}_{\mathbf{1 6}}$ \\
\hline WA1 & $471.71 \pm 6.64^{\mathrm{a}}$ & $730.78 \pm 7.62^{\mathrm{d}}$ & $1109.73 \pm 7.95^{\mathrm{d}}$ & $1580.60 \pm 8.42^{\mathrm{c}}$ & $1998.13 \pm 8.96^{\mathrm{d}}$ & $2331.66 \pm 10.12^{\mathrm{c}}$ & $2637.99 \pm 10.77^{\mathrm{b}}$ \\
$\mathbf{W A 2}$ & $467.63 \pm 5.23^{\mathrm{a}}$ & $767.42 \pm 6.20^{\mathrm{c}}$ & $1177.51 \pm 7.07^{\mathrm{c}}$ & $1648.92 \pm 6.52^{\mathrm{b}}$ & $2053.67 \pm 7.96^{\mathrm{c}}$ & $2403.77 \pm 8.81^{\mathrm{b}}$ & $2731.20 \pm 9.28^{\mathrm{a}}$ \\
$\mathbf{W A 3}$ & $475.81 \pm 4.17^{\mathrm{a}}$ & $821.95 \pm 4.52^{\mathrm{b}}$ & $1220.33 \pm 5.48^{\mathrm{b}}$ & $1686.09 \pm 5.07^{\mathrm{a}}$ & $2072.47 \pm 5.79^{\mathrm{b}}$ & $2422.11 \pm 5.66^{\mathrm{a}}$ & $2737.74 \pm 5.62^{\mathrm{a}}$ \\
$\mathbf{W A 4}$ & $473.32 \pm 5.14^{\mathrm{a}}$ & $849.12 \pm 5.44^{\mathrm{a}}$ & $1264.83 \pm 5.75^{\mathrm{a}}$ & $1698.36 \pm 5.89^{\mathrm{a}}$ & $2101.74 \pm 6.47^{\mathrm{a}}$ & $2434.90 \pm 6.92^{\mathrm{a}}$ & $2734.81 \pm 7.02^{\mathrm{a}}$ \\
\hline
\end{tabular}

$\mathrm{BW}_{4-16}$ : Body weight at 4,6,8,10,12,14,16 weeks of age. WA: Weaning ages 1, 2, 3, and 4 mean weaning ages at less or equal than day 28, between 29 and 35 days, between 35 and 40 days, and more than day 40 respectively. ${ }^{\text {a-d }}$ : Means within columns with no common superscript differ significantly (p $<0.05)$. 
Table 3 shows the effects of age at weaning on BW from 4 weeks up to 16 weeks of age. The mean weights at 4 weeks of age were similar among the different weaning ages due to the experimental design. The results indicated that at 6 weeks of age, the differences in BW were economically important with significant differences. The BW of the kits weaned older than 35 days of age was significantly higher than those weaned before 35 days at BW16 (p > 0.05).

Moreover, the previous result continued until were increased until 8 weeks to be $98.96 \mathrm{~g}$ per animal and the lowest weight achieved by the animals that were weaned early (WA1). At the end of the fattening period ( $\left.\mathrm{BW}_{10}\right)$, the animals of WA3 and WA4 were the heaviest; moreover, there were no significant differences between the rabbit of WA3 and WA4. While rabbits of WA1 were still affected by weaning age with economically relevant differences of 68.32, 105.49, and $117.76 \mathrm{~g}$ per animal at WA2, WA3, and WA4, respectively. The negative effects of early weaning on BW were compensated after 8 weeks of age where the observed differences in BW decreased between kits weaned at different ages and these differences were non-significant between the rabbits that weaned after 35 days. At 16 weeks, the only significant differences were observed between these animals weaned at a younger age (before 30) than those weaned after 30 days of age (at least $94 \mathrm{~g}$ per kit).

Similar results observed by Gallois et al. (2004) indicated the live weight of rabbits weaned at an early age remained lower than late-weaned rabbits. Forthermore, Kovács et al. (2012) and El-Sabrout and Aggag (2017) found that, at market age, rabbits weaned early ( $\leq 28$ days) had significantly lower BW than those weaned later ( $35 \mathrm{~d})$. In addition, McNitt and Moody (1992) and Ferguson et al. (1997) found that kits weaned at 14 days had lower growth and mortality than kits weaned at 28 days. Weaning early (less than 28 days) has shown a series of disorders related to the replacement from consumption of the milk to the granulated diet, which leads to contradictory results. The early weaning may be less problematic with the intake of solid food as Gidenne and Fortun-Lamothe (2002) found that kits weaned at an early age did not ingest any feed for 1 or 2 days. Xiccato et al. (2000, 2003) compared kits weaned at different ages $(21,25,28$, and 32 days) and observed that kits weaned early (21 and 25 days) had a lower weight at 32 days (678 and $679 \mathrm{~g}$, respectively) than those weaned at 28 and 32 days (704 and $719 \mathrm{~g}$, respectively). Moreover, Gabr et al. (2017) reported that the weaning of young rabbits is a complex process with many impacts of dietary, environmental, and psychological stress, which results in inconsistent weight gain, weight loss, and possible total cessation of growth, and even death. Similar results have recently been obtained by Gidenne and Fortun-Lamothe (2002) although with higher mortality at the beginning of the fattening period (32 to 45 days) for the kits weaned early despite using a specific weaning diet (17.2 and 9.2\% mortality for rabbits weaned at 23 and 32 days, respectively). Furthermore, late weaning has the advantage of reduced stress in young rabbits (Marongiu and Gulinati, 2008) because this stress could create some serious health problems within the young rabbits whose gut microbiota is still undeveloped. With increasing age, the gut microbe population increases continuously (Bennegadi et al., 2003). The obtained results of a study conducted by Gallois et al. (2007) showed the protective effect of milk intake in the young rabbit challenged with diseases of the intestine which are frequently seen during the post-weaning period.

As can be seen in Table 4, Genotype $\times$ weaning age interaction is analyzed regarding BW of the different ages. There are clear indications for Genotype $\times$ weaning age interactions for $\mathrm{BW}$ at the end of the fattening period $\left(\mathrm{BW}_{10}\right)$ as well as the consecutive BWs. The superior BWs in APRI were achieved when the weaning was carried out after 30 days while the higher weight for the $\mathrm{V}$ line was when the weaning age was after 35 days. So, as these results illustrate, the rabbit breeder should wean the young rabbits of $\mathrm{V}$ line at late ages (at least 35 days of age) to obtain the highest levels of weight under Egyptian conditions and the those in APRI line could be weaned after 30 days of age.

Table 4. Effect of rabbit lines (APRI and V lines) and weaning ages on body weight during the fattening period

\begin{tabular}{|c|c|c|c|c|c|c|c|c|}
\hline \multirow{2}{*}{ Strain } & \multirow{2}{*}{ WA } & \multicolumn{7}{|c|}{ Triats (g) } \\
\hline & & $\mathrm{BW}_{4}$ & $\mathrm{BW}_{6}$ & $\mathbf{B W}_{8}$ & $\mathrm{BW}_{10}$ & $\mathrm{BW}_{12}$ & $\mathrm{BW}_{14}$ & $\mathrm{BW}_{16}$ \\
\hline \multirow{4}{*}{ APRI } & WA1 & $509.28 \pm 10.97^{\mathrm{a}}$ & $780.07 \pm 11.94^{\mathrm{d}}$ & $1172.84 \pm 12.11^{\mathrm{c}}$ & $1646.37 \pm 12.13^{\mathrm{b}}$ & $2090.09 \pm 12.45^{\mathrm{d}}$ & $2454.59 \pm 12.45^{\mathrm{b}}$ & $2779.22 \pm 12.30^{c}$ \\
\hline & WA2 & $505.88 \pm 7.30^{\mathrm{a}}$ & $821.10 \pm 9.57^{\mathrm{c}}$ & $1234.69 \pm 10.24^{\mathrm{b}}$ & $1713.38 \pm 8.99^{\mathrm{a}}$ & $2154.00 \pm 10.36^{\mathrm{b}}$ & $2532.86 \pm 10.78^{a}$ & $2865.32 \pm 11.13^{\mathrm{a}}$ \\
\hline & WA3 & $518.74 \pm 5.58^{\mathrm{a}}$ & $850.02 \pm 6.51^{\mathrm{b}}$ & $1247.50 \pm 7.24^{\mathrm{b}}$ & $1730.50 \pm 6.30^{\mathrm{a}}$ & $2124.33 \pm 8.40^{\mathrm{c}}$ & $2470.91 \pm 8.23^{\mathrm{b}}$ & $2797.58 \pm 7.17^{\mathrm{c}}$ \\
\hline & WA4 & $511.22 \pm 8.19^{\mathrm{a}}$ & $898.21 \pm 8.06^{\mathrm{a}}$ & $1305.02 \pm 8.41^{\mathrm{a}}$ & $1733.93 \pm 9.08^{\mathrm{a}}$ & $2181.35 \pm 8.46^{\mathrm{a}}$ & $2526.48 \pm 8.56^{\mathrm{a}}$ & $2827.16 \pm 8.80^{\mathrm{b}}$ \\
\hline \multirow{4}{*}{$\mathrm{V}$ line } & WA1 & $430.51 \pm 5.77^{\mathrm{b}}$ & $676.75 \pm 7.50^{\mathrm{f}}$ & $1040.53 \pm 7.43^{\mathrm{e}}$ & $1508.49 \pm 9.21^{\mathrm{d}}$ & $1897.30 \pm 8.25^{\mathrm{g}}$ & $2191.94 \pm 8.17^{\mathrm{f}}$ & $2478.03 \pm 8.19^{\mathrm{g}}$ \\
\hline & WA2 & $428.08 \pm 6.60^{\mathrm{b}}$ & $711.92 \pm 5.95^{\mathrm{e}}$ & $1118.39 \pm 8.12^{\mathrm{d}}$ & $1582.27 \pm 7.27^{\mathrm{c}}$ & $1949.94 \pm 7.63^{\mathrm{f}}$ & $2274.67 \pm 7.01^{\mathrm{e}}$ & $2597.69 \pm 7.76^{\mathrm{f}}$ \\
\hline & WA3 & $433.08 \pm 4.71^{\mathrm{b}}$ & $794.00 \pm 5.72^{\mathrm{d}}$ & $1193.28 \pm 7.83^{\mathrm{c}}$ & $1641.88 \pm 6.76^{\mathrm{b}}$ & $2020.84 \pm 6.32^{\mathrm{e}}$ & $2374.21 \pm 6.26^{\mathrm{c}}$ & $2677.90 \pm 6.47^{\mathrm{d}}$ \\
\hline & WA4 & $434.57 \pm 4.99^{\mathrm{b}}$ & $798.95 \pm 5.60^{\mathrm{d}}$ & $1223.76 \pm 6.86^{\mathrm{c}}$ & $1662.02 \pm 6.66^{\mathrm{b}}$ & $2020.37 \pm 6.22^{\mathrm{e}}$ & $2344.56 \pm 6.61^{\mathrm{d}}$ & $2643.31 \pm 6.49^{\mathrm{e}}$ \\
\hline
\end{tabular}

$\mathrm{BW}_{4-16}$ : Body weight at 4,6,8,10,12,14,16 weeks of age. WA: Weaning ages 1, 2, 3, and 4 mean weaning ages at less or equal than day 28 , between 29 and 35 days, between 35 and 40 days, and more than day 40 respectively. ${ }^{a-g}$ : Means within columns with no common superscript differ significantly (p $<0.05)$. Values are least-squares means. 
It seems that rabbits in the $\mathrm{V}$ line are affected by weaning age more than those in the APRI line where the differences between WA1 and WA4 in V and APRI lines were 153.53 and 87.56, respectively. Later weaning is better for the kits of V line, compared to other lines, such as Spanish ones, since less milk is produced (El Nagar et al., 2014). Moreover, El-Sabrout and Aggag (2017) found that rabbits from the V line weaned later (at 33 days) had significantly higher BW at 63 days (market age) than rabbits weaned earlier (at 23 and $28 \mathrm{~d}$ of age). Identical results were found by Marongiu and Gulinati (2008) when they compared different rabbit genotypes and found that rabbits of California were heavier than New Zealand White ones at the same weaning age which suggested an interactive effect of genotype with weaning age. At the end of the study period, there was a clear line-weaning age interaction where the rabbits of APRI line in WA2 were the heaviest while the heaviest rabbits of V line were at WA3.

The statistical results for average daily gain traits are shown in Table 5. The phenotypic means of ADG (g/d) during the fattening period (until 10 weeks) and the rest of the study period for the different lines are presented in Table 6 . It should be noted that in the whole fattening period $\left(\mathrm{ADG}_{4-10}\right)$, the $\mathrm{ADG}$ values at the initial period (4-6 weeks) were lower than the rest of the fattening period and after the 6 weeks of age while the ADG increased to achieve the maximum growth rate during the period from 8-10 weeks of age. Line APRI was growing faster for the whole fattening period (4$10 \mathrm{wk}$ ) with respect to the $\mathrm{V}$ line (28.47 versus 27.85). Regarding the ADG after the fattening period, APRI lines significantly gained higher weights per day than V line in whole the period (10-16 weeks) (2.26 g/day per rabbit). Moreover, during the entire period from 4 to 16 weeks of age, the observed difference was 1.49 g/d favoring the APRI line.

The obtained results of weaning age effects on ADG traits can be observed in Table 7. The pattern of weaning age effects in the first 2 weeks of growth was different from the pattern for the whole period. The ADG $4-6$ values in all weaning ages were lower than the rest of the whole period. For the whole fattening period (4 -10 weeks), a negative effect of early weaning was significant when the weaned rabbits after $28 \mathrm{~d}$ of age had a higher daily gain than rabbits weaned at $28 \mathrm{~d}$ to be at least $1.72 \mathrm{~g} / \mathrm{d}$ per rabbit. At the end of the fattening period $\left(\mathrm{ADG}_{8-10}\right)$, the inverse situation was found where the differences in favor of rabbits weaned at late age were compensated, and finally, $\mathrm{ADG}$ 8-10 for $\mathrm{WA}_{1}$ was the highest.

Considering the weaning age, it is better to wean the rabbit after 35 days under Egyptian conditions, and the weaning age of 28 days is not recommended in such a condition. After the fattening period, the ADG values were similar. Although these differences were statistically significant, these values did not exceed $0.5 \mathrm{~g} / \mathrm{d}$ in WA1, WA3, and WA4. The lowest growth rate was in rabbits weaned late and the highest ADG was reported in rabbits in WA2. Similarly, Cesari et al. (2007) and Kovács et al. (2012) observed that the growth of rabbits weaned later was higher than those weaned early

Table 8 shows the line-weaning age interaction effects on ADG during the studied period. The $\mathrm{V}$ line seems to be more affected by weaning age than the APRI line. The line APRI had a 7.53\% increased daily gain in late weaned rabbits than early weaning while the V line was affected by 13.87\%. After 6 weeks of age, the ADG values in WA1, WA2, and WA3 were higher than ADG in WA4. In contrast, line V had the lowest ADG after 6 weeks of age, being significant among early weaning periods (WA1, WA2, and WA3). The highest values were obtained in WA2 and WA3 for the APRI line while for the V line the highest values were for WA3 and WA4. Also, the effect of WA on ADG in V line was more significant than that in APRI line from 4 to 16 weeks.

Table 5. Basic statistics for average daily gain traits of rabbits at different ages

\begin{tabular}{|c|c|c|c|c|c|}
\hline Traits (g) & $\mathbf{N}$ & Mean & SD & Minimum & Maximum \\
\hline $\mathrm{ADG}_{4-6}$ & 1799 & $22.95 \pm 0.13$ & 5.93 & 1.20 & 46.07 \\
\hline $\mathbf{A D G}_{6-8}$ & 1798 & $28.68 \pm 0.08$ & 3.43 & 2.49 & 45.28 \\
\hline $\mathbf{A D G}_{8-10}$ & 1799 & $32.87 \pm 0.12$ & 5.47 & 10.28 & 43.71 \\
\hline $\mathbf{A D G}_{10-12}$ & 1794 & $28.87 \pm 0.11$ & 4.98 & 1.6 & 42.50 \\
\hline $\mathrm{ADG}_{12-14}$ & 1715 & $24.40 \pm 0.06$ & 2.67 & 4.28 & 40.28 \\
\hline $\mathbf{A D G}_{14-16}$ & 1692 & $22.30 \pm 0.06$ & 2.47 & 10 & 40.35 \\
\hline $\mathbf{A D G}_{6-10}$ & 1799 & $30.77 \pm 0.06$ & 2.66 & 13.74 & 48.14 \\
\hline $\mathbf{A D G}_{4-10}$ & 1799 & $28.16 \pm 0.05$ & 2.40 & 15.75 & 36.11 \\
\hline $\mathrm{ADG}_{10-16}$ & 1692 & $25.05 \pm 0.04$ & 2.00 & 11.42 & 34.04 \\
\hline $\mathrm{ADG}_{4-16}$ & 1692 & $26.63 \pm 0.03$ & 1.45 & 19.24 & 31.76 \\
\hline
\end{tabular}

*ADG: Average daily gain (g/d), N: Number of observation, SD: Standard deviation. 
Table 6. Effect of rabbit lines (APRI and V lines) on average daily gain traits between different ages

\begin{tabular}{|c|c|c|c|c|c|c|c|c|c|c|}
\hline $\begin{array}{ll}\text { Lines } & \text { Triats } \\
\end{array}$ & $\begin{array}{c}\mathbf{A D G}_{4-6} \\
(\mathrm{~g} / \mathrm{d})\end{array}$ & $\begin{array}{l}\mathbf{A D G}_{6-8} \\
(\mathrm{~g} / \mathrm{d})\end{array}$ & $\begin{array}{c}\mathbf{A D G}_{8-10} \\
(\mathrm{~g} / \mathrm{d})\end{array}$ & $\begin{array}{c}\mathbf{A D G}_{4-10} \\
(\mathrm{~g} / \mathrm{d})\end{array}$ & $\begin{array}{c}\mathbf{A D G}_{6-10} \\
(\mathrm{~g} / \mathrm{d})\end{array}$ & $\underset{(\mathrm{g} / \mathrm{d})}{\mathbf{A D G}_{10-12}}$ & $\underset{(\mathrm{g} / \mathrm{d})}{\mathbf{A D G}_{12-14}}$ & $\begin{array}{l}\mathbf{A D G}_{14-16} \\
(\mathrm{~g} / \mathrm{d})\end{array}$ & $\begin{array}{l}\mathbf{A D G}_{10-16} \\
(\mathrm{~g} / \mathrm{d})\end{array}$ & $\begin{array}{c}\mathbf{A D G}_{4-16} \\
(\mathrm{~g} / \mathrm{d})\end{array}$ \\
\hline APRI & $23.34 \pm 0.16^{\mathrm{a}}$ & $28.79 \pm 0.08^{\mathrm{a}}$ & $33.27 \pm 0.14^{\mathrm{a}}$ & $28.47 \pm 0.05^{\mathrm{a}}$ & $31.03 \pm 0.06^{\mathrm{a}}$ & $\begin{array}{c}30.98 \\
\pm 0.12^{\mathrm{a}}\end{array}$ & $25.52 \pm 0.06^{\mathrm{a}}$ & $22.81 \pm 0.09^{\mathrm{a}}$ & $26.17 \pm 0.04^{\mathrm{a}}$ & $27.36 \pm 0.92^{\mathrm{a}}$ \\
\hline $\mathbf{V}$ & $22.54 \pm 0.22^{\mathrm{b}}$ & $28.55 \pm 0.14^{b}$ & $32.45 \pm 0.21^{\mathrm{b}}$ & $27.85 \pm 0.09^{b}$ & $30.50 \pm 0.10^{b}$ & $26.69 \pm 0.16^{b}$ & $23.26 \pm 0.10^{\mathrm{b}}$ & $21.78 \pm 0.06^{b}$ & $23.91 \pm 0.06^{\mathrm{b}}$ & $25.87 \pm 0.50^{b}$ \\
\hline
\end{tabular}

ADG: Average daily gain $(\mathrm{g} / \mathrm{d}){ }^{\mathrm{a}-\mathrm{b}:}$ Means within columns with no common superscript differ significantly $(\mathrm{p}<0.05)$. Values are least-squares means.

Table 7. Effect of weaning age on average daily gain traits between different ages.

\begin{tabular}{|c|c|c|c|c|c|c|c|c|c|c|}
\hline WA & $\begin{array}{c}\mathbf{A D G}_{\mathbf{4 - 6}} \\
(\mathrm{g} / \mathrm{d})\end{array}$ & $\begin{array}{c}\mathbf{A D G}_{\mathbf{6 - 8}} \\
(\mathrm{g} / \mathrm{d})\end{array}$ & $\begin{array}{c}\text { ADG }_{8-10} \\
(\mathrm{~g} / \mathrm{d})\end{array}$ & $\begin{array}{c}\mathbf{A D G}_{4-10} \\
(\mathrm{~g} / \mathrm{d})\end{array}$ & $\begin{array}{c}\mathbf{A D G}_{6-10} \\
(\mathrm{~g} / \mathrm{d})\end{array}$ & $\begin{array}{c}\mathbf{A D G}_{\mathbf{1 0 - 1 2}} \\
(\mathrm{g} / \mathrm{d})\end{array}$ & $\begin{array}{c}\mathbf{A D G}_{12-14} \\
(\mathrm{~g} / \mathrm{d})\end{array}$ & $\begin{array}{c}\mathbf{A D G}_{14-16} \\
(\mathrm{~g} / \mathrm{d})\end{array}$ & $\begin{array}{c}\mathbf{A D G}_{10-16} \\
(\mathrm{~g} / \mathrm{d})\end{array}$ & $\begin{array}{c}\mathbf{A D G}_{4-16} \\
(\mathrm{~g} / \mathrm{d})\end{array}$ \\
\hline WA1 & $18.50 \pm 0.27^{\mathrm{d}}$ & $27.08 \pm 0.17^{\mathrm{c}}$ & $33.63 \pm 0.23^{\mathrm{b}}$ & $26.40 \pm 0.13^{\mathrm{d}}$ & $30.35 \pm 0.15^{\mathrm{c}}$ & $29.82 \pm 0.25^{\mathrm{a}}$ & $23.41 \pm 0.14^{\mathrm{c}}$ & $21.64 \pm 0.08^{\mathrm{c}}$ & $25.05 \pm 0.12^{b}$ & $25.80 \pm 0.08^{b}$ \\
\hline WA2 & $21.41 \pm 0.27^{\mathrm{c}}$ & $29.29 \pm 0.15^{\mathrm{a}}$ & $33.67 \pm 0.18^{\mathrm{a}}$ & $28.12 \pm 0.11^{\mathrm{c}}$ & $31.48 \pm 0.09^{\mathrm{a}}$ & $28.91 \pm 0.19^{\mathrm{b}}$ & $24.72 \pm 0.14^{\mathrm{a}}$ & $23.12 \pm 0.11^{\mathrm{a}}$ & $25.62 \pm 0.10^{\mathrm{a}}$ & $26.89 \pm 0.08^{\mathrm{a}}$ \\
\hline WA3 & $\begin{array}{c}24.72 \\
\pm 0.20^{b}\end{array}$ & $\begin{array}{c}28.45 \\
\pm 0.15^{\mathrm{b}}\end{array}$ & $\begin{array}{c}33.26 \\
\pm 0.33^{\mathrm{c}}\end{array}$ & $\begin{array}{c}28.81 \\
\pm 0.06^{\mathrm{b}}\end{array}$ & $\begin{array}{c}30.86 \\
\pm 0.13^{\text {b }}\end{array}$ & $\begin{array}{c}28.02 \\
\pm 0.24^{\mathrm{c}}\end{array}$ & $\begin{array}{c}24.93 \\
\pm 0.05^{\mathrm{a}}\end{array}$ & $\begin{array}{c}22.48 \\
\pm 0.16^{\mathrm{b}}\end{array}$ & $\begin{array}{c}25.01 \\
\pm 0.08^{\mathrm{b}}\end{array}$ & $\begin{array}{c}26.91 \\
\pm 0.04^{\mathrm{a}}\end{array}$ \\
\hline WA4 & $\begin{array}{c}26.84 \\
\pm 0.18^{\mathrm{a}}\end{array}$ & $\begin{array}{c}29.69 \\
\pm 0.14^{\mathrm{a}}\end{array}$ & $\begin{array}{c}30.96 \\
\pm 0.24^{\text {c }}\end{array}$ & $\begin{array}{c}29.1 \\
\pm 0.08^{\mathrm{a}}\end{array}$ & $\begin{array}{c}30.33 \\
\pm 0.11^{\mathrm{c}}\end{array}$ & $\begin{array}{c}28.81 \\
\pm 0.23^{\mathrm{b}}\end{array}$ & $\begin{array}{c}24.43 \\
\pm 0.12^{\mathrm{b}}\end{array}$ & $\begin{array}{c}21.87 \\
\pm 0.07^{\mathrm{c}}\end{array}$ & $\begin{array}{c}24.51 \\
\pm 0.06^{\mathrm{c}}\end{array}$ & $\begin{array}{c}26.81 \\
\pm 0.04^{\mathrm{a}}\end{array}$ \\
\hline
\end{tabular}

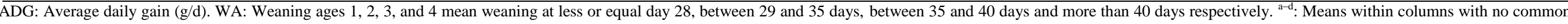
superscript differ significantly $(\mathrm{p}<0.05)$. Values are least-squares means.

Table 8. Effects of rabbit lines (APRI and V lines) and weaning ages on average daily gain traits between different ages

\begin{tabular}{|c|c|c|c|c|c|c|c|c|c|c|c|}
\hline \multirow[b]{2}{*}{ Lines } & \multirow[b]{2}{*}{ WA } & \multicolumn{10}{|c|}{ Traits } \\
\hline & & $\begin{array}{c}\mathbf{A D G}_{\mathbf{4 - 6}} \\
(\mathrm{g} / \mathrm{d})\end{array}$ & $\begin{array}{c}\mathbf{A D G}_{6-8} \\
(\mathrm{~g} / \mathrm{d})\end{array}$ & $\begin{array}{c}\text { ADG }_{8-10} \\
(\mathrm{~g} / \mathrm{d})\end{array}$ & $\begin{array}{c}\mathbf{A D G}_{4-10} \\
(\mathrm{~g} / \mathrm{d})\end{array}$ & $\begin{array}{c}\mathbf{A D G}_{6-10} \\
(\mathrm{~g} / \mathrm{d})\end{array}$ & $\begin{array}{c}\mathbf{A D G}_{\mathbf{1 0 - 1 2}} \\
(\mathrm{g} / \mathrm{d})\end{array}$ & $\begin{array}{c}\mathbf{A D G}_{\mathbf{1 2 - 1 4}} \\
(\mathrm{g} / \mathrm{d})\end{array}$ & $\begin{array}{c}\mathbf{A D G}_{(\mathrm{g} / \mathrm{16}} \\
(\mathrm{g} / \mathrm{d})\end{array}$ & $\begin{array}{c}\mathbf{A D G}_{\mathbf{1 0 - 1 6}} \\
(\mathrm{g} / \mathrm{d})\end{array}$ & $\begin{array}{c}\mathbf{A D G}_{4-16} \\
(\mathrm{~g} / \mathrm{d})\end{array}$ \\
\hline \multirow{4}{*}{ APRI } & WA1 & $19.34 \pm 0.21^{\mathrm{f}}$ & $28.09 \pm 0.11^{\mathrm{d}}$ & $33.82 \pm 0.13^{\mathrm{ab}}$ & $27.07 \pm 0.08^{\mathrm{d}}$ & $30.93 \pm 0.07^{\circ}$ & $31.69 \pm 0.12^{\mathrm{a}}$ & $25.81 \pm 0.06^{b}$ & $22.89 \pm 0.06^{\mathrm{a}}$ & $26.85 \pm 0.04^{\mathrm{b}}$ & $27.02 \pm 0.03^{\mathrm{c}}$ \\
\hline & WA2 & $22.51 \pm 0.30^{\mathrm{d}}$ & $29.54 \pm 0.15^{\mathrm{b}}$ & $34.19 \pm 0.29^{\mathrm{ab}}$ & $28.75 \pm 0.10^{\mathrm{b}}$ & $31.86 \pm 0.13^{\mathrm{a}}$ & $31.47 \pm 0.23^{\mathrm{a}}$ & $26.44 \pm 0.15^{\mathrm{a}}$ & $23.26 \pm 0.16^{\mathrm{a}}$ & $27.16 \pm 0.10^{\mathrm{a}}$ & $27.99 \pm 0.07^{\mathrm{a}}$ \\
\hline & WA3 & $23.66 \pm 0.20^{\mathrm{c}}$ & $28.39 \pm 0.20^{\mathrm{d}}$ & $34.50 \pm 0.34^{\mathrm{a}}$ & $28.85 \pm 0.08^{\mathrm{ab}}$ & $31.44 \pm 0.10^{\mathrm{ab}}$ & $28.72 \pm 0.35^{\mathrm{b}}$ & $24.86 \pm 0.09^{\mathrm{d}}$ & $23.31 \pm 0.31^{\mathrm{a}}$ & $25.40 \pm 0.08^{\mathrm{c}}$ & $27.10 \pm 0.05^{\mathrm{c}}$ \\
\hline & WA4 & $\begin{array}{c}27.64 \\
\pm 0.28^{\mathrm{a}}\end{array}$ & $\begin{array}{c}29.05 \\
\pm 0.16^{\mathrm{bc}}\end{array}$ & $\begin{array}{c}30.63 \\
\pm 0.24^{\mathrm{d}}\end{array}$ & $\begin{array}{c}29.11 \\
\pm 0.12^{\mathrm{ab}}\end{array}$ & $\begin{array}{c}29.84 \\
\pm 0.13^{\mathrm{de}}\end{array}$ & $\begin{array}{c}31.95 \\
\pm 0.22^{\mathrm{a}}\end{array}$ & $\begin{array}{c}24.92 \\
\pm 0.10^{\mathrm{c}}\end{array}$ & $\begin{array}{c}21.77 \\
\pm 0.07^{\mathrm{b}}\end{array}$ & $\begin{array}{c}25.25 \\
\pm 0.06^{\mathrm{c}}\end{array}$ & $\begin{array}{c}27.30 \\
\pm 0.05^{\mathrm{b}}\end{array}$ \\
\hline \multirow{4}{*}{ V-Line } & WA1 & $\begin{array}{c}17.58 \\
\pm 0.51^{\mathrm{g}}\end{array}$ & $\begin{array}{l}25.98 \\
\pm 0.31^{\text {e }}\end{array}$ & $\begin{array}{c}33.42 \\
\pm 0.46^{\mathrm{b}}\end{array}$ & $\begin{array}{c}25.66 \\
\pm 0.25^{\mathrm{e}}\end{array}$ & $\begin{array}{c}29.70 \\
\pm 0.30^{\text {e }}\end{array}$ & $\begin{array}{c}27.77 \\
\pm 0.47^{\mathrm{c}}\end{array}$ & $\begin{array}{c}20.67 \\
\pm 0.13^{\mathrm{f}}\end{array}$ & $\begin{array}{c}20.22 \\
\pm 0.08^{\mathrm{c}}\end{array}$ & $\begin{array}{c}23.00 \\
\pm 0.17^{\mathrm{g}}\end{array}$ & $\begin{array}{c}24.42 \\
\pm 0.11^{\mathrm{g}}\end{array}$ \\
\hline & WA2 & $\begin{array}{c}20.27 \\
\pm 0.44^{\mathrm{e}}\end{array}$ & $\begin{array}{c}29.03 \\
\pm 0.26^{\mathrm{bc}}\end{array}$ & $\begin{array}{c}33.13 \\
\pm 0.20^{\mathrm{b}}\end{array}$ & $\begin{array}{c}27.48 \\
\pm 0.19^{\mathrm{c}}\end{array}$ & $\begin{array}{c}31.08 \\
\pm 0.13^{\mathrm{cb}}\end{array}$ & $\begin{array}{c}26.26 \\
\pm 0.20^{\mathrm{d}}\end{array}$ & $\begin{array}{c}22.99 \\
\pm 0.17^{\mathrm{e}}\end{array}$ & $\begin{array}{c}22.99 \\
\pm 0.15^{\mathrm{a}}\end{array}$ & $\begin{array}{c}24.08 \\
\pm 0.08^{\mathrm{e}}\end{array}$ & $\begin{array}{c}25.80 \\
\pm 0.10^{\mathrm{f}}\end{array}$ \\
\hline & WA3 & $\begin{array}{c}25.78 \\
\pm 0.33^{\mathrm{b}}\end{array}$ & $\begin{array}{c}28.51 \\
\pm 0.23^{\mathrm{cd}}\end{array}$ & $\begin{array}{c}32.04 \\
\pm 0.56^{\mathrm{c}}\end{array}$ & $\begin{array}{c}28.78 \\
\pm 0.10^{\mathrm{b}}\end{array}$ & $\begin{array}{c}30.28 \\
\pm 0.24^{\mathrm{d}}\end{array}$ & $\begin{array}{c}27.33 \\
\pm 0.34^{\mathrm{c}}\end{array}$ & $\begin{array}{c}25.01 \\
\pm 0.14^{\mathrm{c}}\end{array}$ & $\begin{array}{c}21.64 \\
\pm 0.06^{\mathrm{b}}\end{array}$ & $\begin{array}{c}24.62 \\
\pm 0.13^{\mathrm{d}}\end{array}$ & $\begin{array}{c}26.71 \\
\pm 0.06^{\mathrm{d}}\end{array}$ \\
\hline & WA4 & $\begin{array}{c}26.02 \\
\pm 0.24^{b}\end{array}$ & $\begin{array}{c}30.34 \\
\pm 0.23^{\mathrm{a}}\end{array}$ & $\begin{array}{c}31.30 \\
\pm 0.41^{\mathrm{cd}}\end{array}$ & $\begin{array}{c}29.22 \\
\pm 0.10^{\mathrm{a}}\end{array}$ & $\begin{array}{c}30.82 \\
\pm 0.16^{\mathrm{c}}\end{array}$ & $\begin{array}{c}25.59 \\
\pm 0.29^{\mathrm{d}}\end{array}$ & $\begin{array}{c}23.96 \\
\pm 0.21^{\mathrm{d}}\end{array}$ & $\begin{array}{c}21.96 \\
\pm 0.12^{\mathrm{b}}\end{array}$ & $\begin{array}{c}23.79 \\
\pm 0.08^{\mathrm{f}}\end{array}$ & $\begin{array}{c}26.33 \\
\pm 0.04^{\mathrm{e}}\end{array}$ \\
\hline
\end{tabular}

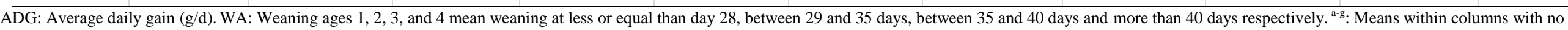
common superscript differ significantly $(\mathrm{p}=0.05)$. Values are least-squares means. 


\section{CONCLUSIONS}

Considering Egyptian conditions, the early weaning had negative effects on growth traits during the fattening period, but these negative effects were compensated after 8 weeks of age. Early weaning (before $28 \mathrm{~d}$ ) is not recommended for Egyptian rabbits. Clear indications of Genotype $\times$ weaning age $(\mathrm{G} \times \mathrm{WA})$ interactions were observed for growth traits where $\mathrm{V}$ line is affected by weaning age than the APRI line. It is recommended to wean the young rabbit of APRI between 29-35 days while in $\mathrm{V}$ line is recommended the weaning age after 35 days. However, comparison studies between APRI line and V line about weaning age and its effect on the incidences of pathology are required.

\section{DECLARATIONS}

\section{Authors' contributions}

M.R., K.H.E, L.M.R., A.E. and I.T.E. developed the concept of the manuscript. M.R. wrote the manuscript. All authors checked and confirmed the final revised manuscript.

\section{Competing interests}

None of the authors have any conflict of interest to declare

\section{Ethical considerations}

M.R., K.H.E, L.M.R., A.E., and I.T.E. had full access to all data in the study and took responsibility for the integrity of the data and the accuracy of the data analysis as well as ethical issues (including plagiarism, consent to publish, misconduct, data fabrication and/or falsification, double publication and/or submission, and redundancy). All authors confirmed the final edition of the article and declared that they did not use any related data of this article on any other publications.

\section{REFERENCES}

Abou Khadiga G, Youssef YMK, Saleh K, Nofal RY, and Baselga M (2010). Genetic trend in selection for litter weight in two maternal lines of rabbits in Egypt. World Rabbit Science, 18: 27-32. DOI: http://www.doi.org/10.4995/wrs.2010.18.04

Arias-Alvarez M, Garcia-Garcia RM, Rebollar PG, Nicodemus N, Revuelta L, Millán P, and Lorenzo PL (2009). Influence of metabolic status on oocyte quality and follicular characteristics at different postpartum periods in primiparous rabbit does. Theriogenology, 72: 612-623. DOI: https://www.doi.org/10.1016/j.theriogenology.2009.04.017

Bennegadi N, Fonty G, Ginnede T, and Licois D (2003). Effects of age and dietary fibre level on caecal microbial communities of conventional and specific pathogen-free rabbits. Microbial Ecology in Health and Disease, 5: 23-32. DOI: https://www.doi.org/ 10.1080/08910600310015574

Cesari V, Toschi I, Ferrazzi V, Cesari N, Grilli G, and Lavazza A (2007). Effect of weaning age and diet on growth performance, caecal characteristics and potential pathogenic microflora in rabbits. Italalian Journal of Animal Science, 6: 755-757. DOI: https://www.doi.org/ 10.4081/ijas.2007.1s.755

Dalle Zotte A (2002). Perception of rabbit meat quality and major factors influencing the rabbit carcass and meat quality. Liveststock Prouction Science, 75: 11-32. DOI: https://www.doi.org/10.1016/S0301-6226(01) 00308-6.

De Blas JC, Perez E, Fraga M J, Rodriguez JM, and Galvez JF (1981). Effect of diet on feed intake and growth of rabbits from weaning to slaughter at different ages and weights. Journal of Animal Science, 52: 1225-1232. DOI: https://www.doi.org/ 10.2527/jas1981.5261225x

Ebeid TA, Zeweil HS, Basyony MM, Dosoky WM, and Badry H (2013). Fortification of rabbit diets with vitamin E or selenium affects growth performance, lipid peroxidation, oxidative status and immune response in growing rabbits. Livestock Science, 155: 323-331. DOI: https://www.doi.org/10.1016/j.livsci.2013.11.004.

El Nagar AG, Sánchez JP, Ragab M, Mínguez C, and Baselga M (2014). Genetic comparison of milk production and composition in three maternal rabbit lines. World Rabbit Science, 22: 261-268. DOI: https://www.doi.org/10.4995/wrs.2014.1917

El-Sabrout K, and Aggag S (2017). The gene expression of weaning age and its effect on productive performance of rabbits. World Rabbit Science., 25: 1-7. DOI: https://www.doi.org/10.4995/wrs.2017.4777

Estany J, Baselga M, Blasco A, and Camacho J (1989). Mixed model methodology for the estimation of genetic response to selection in litter size of rabbits. Livestock Production Science, 21: 67-76. DOI: https://doi.org/10.1016/0301-6226(89)90021-3

Ferguson FA, Lukefaahr SD, and Mcnitt JI (1997). A technical note on artificial milk feeding of rabbit kits weaned at 14 days. World Rabbit Science, 5: 65-70. DOI: https://www.doi.org/10.4995/wrs.1997.321

Gabr AA, Shalaby NA, and Rahma HM (2017). Effect of weaning age and using mixture of tracts with cow milk as a supplementation on growing rabbits performances. Asian Journal of Animal and Veterenary Advances, 2: 96-102. DOI: https://www.doi.org/10.3923/ajava.2017.96.102

Galal OA, Rehan M, and Abd El-Karim RE (2013). Analysis of genetic diversity within and among four rabbit genotypes using biochemical and molecular genetic markers. African Journal of Biotechenology, 12: 2830-2839 DOI: https://www.doi.org/10.5897/AJB2013.12332 
Gallois M, Gidenne T, Fortun-Lamothe L, Le Huerou-Luron I, and Lalles JP (2004). Weaning age and development of the small intestinal mucosa in the young rabbit. In: Proc. 8th World Rabbit Congress, Puebla, Mexico, pp. 1079-1085. Available at: http://www.world-rabbit-science.com/WRSA-Proceedings/Congress-2004-Puebla/Papers/Physiology-Digestion/D-Gallois.pdf

Gallois M, Gidenne T, Tasca C, Caubet C, Coudert C, Milon A, and Boullier S (2007). Maternal milk contains antimicrobial factors that protect young rabbits from enteropathogenic Escherichia coli infection. Clinical and Vaccine Immunology, 14: 585-592. DOI: https://www.doi.org/10.1128/CVI.00468-06

Gidenne T, and Fortun-Lamothe L (2002). Feeding strategy for young rabbits around weaning: A review of digestive capacity and nutritional needs. Animal Science, 75(2): 169-184. DOI: https://www.doi.org/10.1017/S1357729800052942

Kovács M, Bónai A, Szendrő Z, Milisits G, Lukács H, Szabó-Fodor J, Tornyos G, Matics Z, Kovács F, and Horn P (2012). Effect of different weaning ages $(21,28$ or 35 days) on production, growth and certain parameters of the digestive tract in rabbits. Animal, 6: 894-901. DOI: https://www.doi.org/10.1017/S1751731111002254

Lebas F (1993). Amélioration de la viabilité des lapereaux en engraissement par un sevrage tardif. Cuniculture, 20: 73-75. Available at: https://hal.inrae.fr/view/index/identifiant/hal-02701450

Lukefahr SD, Hohenboken WD, Cheeke PR, and Patton NM (1983). Characterization of strainghtbred and crossbred rabbits for milk production and associative traits. Journal of Animal Science, 57: 1100-1107. DOI: https://www.doi.org/10.2527/jas1983.5751100x

Marongiu ML, and Gulinati A (2008). Ultrasound evaluation of ovarian follicular dynamics during early pseudo pregnancy as a tool to inquire into the high progesterone $(\mathrm{P}+)$ syndrome of rabbit does. In: Proceedings of the $9^{\text {th }}$ World Rabbit Congress; June 1013, Verona, Italy. Castanet-Tolosan, France: World Rabbit Science Assoiation, pp. 393-397. Available at http://world-rabbitscience.com/WRSA-Proceedings/Congress-2008-Verona/Papers/R-Marongiu2.pdf

McNitt JI, and Lukefahr SD (1990). Effects of breed, parity, day of lactation and number of kits on milk production of rabbits. Journal of Animal Science, 68: 1505-1512. DOI: https://www.doi.org/10.2527/1990.6861505x

McNitt JI, and Moody GLA (1992). Method for weaning rabbit kits at 14 days. Journal of Appled Animal Research, 15: 661-665. Available at: http://world-rabbit-science.com/WRSA-Proceedings/Congress-1992-Corvallis/Communications-pdf/D10MCNITT.pdf

Orengo J, Gomez EA, Piles M, Rafel O, and Ramon J (2004). Growth traits in simple crossbreeding among dam and sire lines. In: Proceeding of the $8^{\text {th }}$ World Rabbit Congress, September 7-10, Puebla, Mexico, pp. 114-120. Available at: http://world-rabbitscience.com/WRSA-Proceedings/Congress-2004-Puebla/Papers/Genetics/G-Orengo.pdf

Petracci M, Bianchi M, and Cavani C (2009). Development of rabbit meat products fortified with n-3 polyunsaturated fatty acids. Nutrients, 1: 111-118. DOI: https://www.doi.org/10.3390/nu1020111 PMID: 22253971.

Ragab M, and Baselga MA (2011). comparison of reproductive traits of four maternal lines of rabbits selected for litter size at weaning and founded on different criteria. Livestock Science, 136 : 201-206. DOI: https://www.doi.org/10.1016/j.livsci.2010.09.009

Rebollar PG, Pérez-Cabal MA, Pereda N, Lorenzo PL, Arias-Álvarez M, and Garcia-Rebollar P (2009). Effects of parity order and reproductive management on the efficiency of rabbit productive systems. Livestock Science, 123: 107-115. DOI: https://www.doi.org/10.1016/j.livsci.2008.06.018

SAS (2012). Statistical Analysis Software. Software for Statistical Analysis; Version 9.4., SAS Institute Inc.: Cary, NC, USA.

Savietto D, Marono S, Martínez I, Martínez-Paredes E, Ródenas L, Cervera C, and Pascual J (2016). Patterns of body condition use and its impact on fertility. World Rabbit Science, 24(1): 39-45. DOI: https://www.doi.org/10.4995/wrs.2016.4006

Xiccato G, Trocino A, Sartori A, and Queaque P (2003). Effect of weaning diet and weaning age on growth, body composition, and caecal fermentation of young rabbits. Animal Science, 77(1): 101-111. DOI: https://www.doi.org/10.1017/S1357729800053704

Xiccato G, Trocino A, Sartori A, and Queaque PI (2000). Early weaning of rabbits: Effect of age and diet on weaning and postweaning performance. En: Proceeding of the $7^{\text {th }}$ World Rabbit Congress, 4-7 July, 2000, Valencia, Spain, pp. 483-490. Available at: http://world-rabbit-science.com/WRSA-Proceedings/Congress-2000-Valencia/Valencia-2000a.htm\#management

Xiccato G, Trocino A, Sartori A, and Queaque PI (2004). Effect of parity order and litter weaning age on the performance and body energy balance of rabbit does. Livestock Production Science, 85: 239-251. DOI: https://www.doi.org/10.1016/S0301$\underline{\text { 6226(03)00125-8 }}$

Youssef YMK, Baselga M, Khalil MH, Gad-Alla S, and García ML (2008). Evaluation of litter traits in a crossing project of V-line and Baladi Red rabbits in Egypt. Liveststock Research for Rural. Development, 20: Article \#135. Available at: http://www.lrrd.org/lrrd20/9/yous20135.htm 